\title{
Etnomatematika: Eksplorasi Seni Ukir Jepara
}

\author{
Rahmi Nur Fitria Utami, Redi Hermanto, Dedi Muhtadi \\ Program Studi Pendidikan Matematika, Fakultas Keguruan dan Ilmu Pendidikan, \\ Universitas Siliwangi, Kota Tasikmalaya, Indonesia \\ E-mail: rahminurfitriaaa@gmail.com \\ Sukirwan \\ Program Studi Pendidikan Matematika, Fakultas Keguruan dan Ilmu Pendidikan, \\ Universitas Sultan Ageng Tirtayasa, Kota Serang, Indonesia
}

\begin{abstract}
ABSTRAK
Matematika adalah ilmu tentang pola, struktur, dan representasi benda yang tumbuh dan berakar pada kehidupan nyata. Pola, struktur, dan bentuk benda-benda tersebut dapat ditemukan dalam kehidupan sehari-hari dan penerapan konsep matematika yang terintegrasi dalam adat budaya yang disebut etnomatematika. Salah satu konsep matematika tersebut terdapat pada ukiran Jepara. Penelitian ini menggunakan metode deskriptif-kualitatif untuk mendeskripsikan filosofi seni pahat Jepara, unsur-unsur matematika dalam seni pahat Jepara, dan keterkaitan antara kedua fokus studi tersebut. Pengumpulan data menggunakan wawancara, observasi, dan dokumentasi. Subjek penelitian adalah pengrajin ukiran Jepara. Hasil penelitian menunjukkan bahwa: (1) Seni ukir Jepara kaya akan filosofi, meliputi nilai, ajaran, dan kepercayaan yang berkaitan dengan agama, akhlak, dan budaya yang melatarbelakangi ukiran Jepara, (2) unsur matematika terintegrasi dalam pola pikir pengrajin dan diterapkan dalam pembuatan ukiran Jepara, termasuk kegiatan matematika yang berkaitan dengan berhitung, mencari lokasi, mengukur, dan merancang, serta konsep matematika yang berkaitan dengan titik, garis, sudut, gradien, geometri datar, lingkaran, bentuk geometris, kekosongan, dan transformasi geometri refleksi. dan rotasi, (3) filosofi dan unsur matematika secara bersama-sama berperan penting dan mendukung keberadaan seni ukir Jepara menjadi seni yang kaya nilai.
\end{abstract}

Kata kunci: etnomatematika, seni ukir Jepara

\begin{abstract}
Mathematics is the science of patterns, structures, and representation of objects that grow and have their roots in real life. The patterns, structures, and shape of these objects can be found in everyday life and applications of mathematical concepts integrated in cultural customs that called ethnomathematics. One of the ethnomathematics concepts contained on Jepara's carving. This research used descriptive qualitative method to describe Jepara's carving philosophy, mathematical elements in Jepara's carving, and the relationship between the two focus of the study. Data collection using interview, observation, and documentation. The research subjects are Jepara's carving craftsmen. The results showed that: (1) Jepara's carving is rich of philosophy, including values, teachings, and beliefs related to religion, morals, and culture that are background of the Jepara carvings, (2) mathematical elements are integrated in the craftmen's mindset and applied in the making of Jepara's carving, including mathematical activities related to counting, locating, measuring, and designing, and mathematical concepts related to point, line, angle, gradient, flat geometry, circle, geometric shape, blankness, and transformation geometry of reflection and rotation, (3) philosophy and mathematical elements together play an important role and support the existence of Jepara's carving become an art with rich values.
\end{abstract}

Keywords: Ethnomathematics; Jepara's Carving 


\section{PENDAHULUAN}

Seni ukir adalah jenis karya seni rupa yang dibuat dengan teknik goresan, cukilan, atau pahatan pada media kayu, tempurung, dan bahan-bahan lainnya (Depdiknas, 2008:1773). Hasil karya seni ukir ini banyak terdapat di Jepara, yang kerap disebut seni ukir Jepara. Jepara merupakan salah satu kabupaten di Provinsi Jawa Tengah, Indonesia, yang dikenal sebagai kota ukir. Daerah tersebut adalah daerah penghasil ukir kayu utama dan terkenal dengan banyaknya sentra industri seni ukir yang umumnya berupa benda-benda keperluan rumah tangga (Soepratno, 2004:viii).

Awal perkembangan seni ukir Jepara telah ada sejak zaman Kerajaan Demak pada masa pemerintahan Ratu Kalinyamat tahun 1521-1546 Masehi (Nangoy \& Sofiana, 2013:260). Pada masa itu terdapat seorang menteri kerajaan yang memiliki kemampuan mengukir dengan baik bernama Sungging Badarduwung yang diminta oleh Ratu untuk memperindah bangunan Masjid Mantingan dan Makam Jirat, yaitu makam suaminya bernama Sultan Hadlirin dengan ukiran. Sejak saat itu, seni ukir di Jepara berkembang dan terus berlanjut pada masa Kartini, sampai masa modern sekarang ini.

Perkembangan seni ukir Jepara menorehkan catatan panjang tentang budaya masyarakat Jepara hingga masa modern ini tetap terjaga eksistensinya. Untuk mempertahankannya, bermula dari keahlian sekelompok masyarakat Jepara dalam hal mengukir yang kemudian diwariskan secara turun-temurun dari satu generasi ke generasi selanjutnya hingga menjadi budaya yang tak lepas dari kehidupan dan peradaban masyarakat Jepara (Gustami, 2000:251). Tentunya tidak mudah bagi masyarakat Jepara dalam mempertahankan budaya tersebut. Di samping nilai-nilai kepercayaan yang dianut oleh masyarakat Jepara, adanya keterampilan dalam mengaplikasikan ilmu selama proses pembuatannya menambah rentetan keunikan seni ukir Jepara. Dilihat dari bentuknya yang indah, seni ukir Jepara memiliki makna tersendiri tentang bagaimana manusia dapat mengubah sebidang kayu menjadi sebuah karya seni.

Untuk menghasilkan karya seni ukir Jepara, tentunya tidak terlepas dari keterampilan tangan, aktivitas, dan pola berpikir yang dilakukan oleh pengrajin ukiran Jepara, dimana pengrajin perlu melakukan beberapa teknik diantaranya adalah membuat pola, nggetaki (mentransformasikan garis-garis dalam pola di kertas pada kayu), ndasari (mencongkel bagian dasar di luar motif), mbukaki (membentuk pahatan pada motif batang, daun, atau bunga), mbenangi (membentuk benangan atau garis lekukan pada motif), dan finishing (menghaluskan hasil ukiran) (Rahmawati, et al, 2017:31; Soepratno, 2004:89-91). Teknikteknik dalam pembuatan seni ukir Jepara terintegrasi dalam berbagai aktivitas keseharian yang telah menjadi budaya dalam masyarakat Jepara, salah satunya adalah aktivitas mengukur dan membuat pola yang berkaitan erat dengan matematika.

Aktivitas pembuatan seni ukir Jepara merepresentasikan pola pikir matematis manusia berkaitan dengan pengukuran dan pembuatan pola yang diaplikasikan hingga menjadi bentuk karya seni. Kondisi ini berkorelasi dengan definisi matematika, dimana matematika dapat dimaknai sebagai ilmu tentang pola dan hubungan, pola pikir, suatu seni, bahasa, atau alat (Fahrurrozi \& Hamdi, 2017:3; Reys, 1984). Di samping itu, matematika merupakan studi tentang struktur dan pola entitas objek abstrak (Downing, 2009:205; Fahrurrozi \& Hamdi, 2017:3). Struktur dalam definisi matematika menggambarkan bahwa matematika merupakan susunan unsur-unsur yang dibangun dengan pola-pola tertentu, sehingga menghasilkan sebuah karya atau benda. Karya atau benda tersebut merupakan hasil olah pikir manusia yang dikolaborasikan dalam bentuk tindakan dan aktivitas kehidupan. Kemampuan menggunakan akal dan pikiran dalam menangkap sebuah pola untuk 
menyelesaikan suatu masalah dengan menggunakan peralatan yang sederhana ini merupakan esensi dari matematika (Utami, et al, 2020:14). Keterampilan mengenai penggunaan akal dan pikiran dalam menangkap suatu pola ini dimiliki oleh pengrajin ukiran Jepara, dimana untuk menghasilkan karya seni yang indah dibutuhkan kemampuan para pengrajin dalam menangkap berbagai unsur dalam kehidupan kemudian mengolah dan memadupadankannya pada akal dan pikiran hingga terbentuk pola motif lalu mentransformasikannya dalam bentuk ukiran Jepara. Dengan melakukan aktivitas dan proses berpikir tersebut, pengrajin ukiran Jepara dapat menghasilkan sebuah ukiran sebagai seni terapan yang bersifat komersil untuk meningkatkan taraf hidupnya. Dengan demikian, hal ini mempertegas bahwa tanpa disadari praktik matematika telah terintegrasi dalam budaya berupa aktivitas dan pola pikir matematis masyarakat pengrajin ukiran Jepara.

Objek-objek sebagai hasil karya yang dibangun dengan konsep matematika menunjukkan bahwa matematika telah diaplikasikan dalam kehidupan manusia. Objek tersebut diciptakan dengan maksud untuk memenuhi kebutuhan dan membantu manusia dalam melakukan aktivitas kehidupannya. Objek atau hasil karya tersebut dapat berupa alat, perkakas, perabot, bangunan, dan sebagainya, baik itu dalam bentuk sederhana maupun dalam bentuk yang sudah modern. Objek dan hasil karya ini terintegrasi dalam sistem budaya kehidupan masyarakat tertentu, dan disebut dengan istilah etnomatematika. Etnomatematika dapat dimaknai sebagai matematika yang diaplikasikan oleh sekelompok budaya masyarakat, seperti kelompok buruh atau tani, anak-anak dari masyarakat kelas tertentu, kelas profesional, dan lain-lain kapanpun dan dimanapun mereka berada (D'Ambrosio, 1985:45; Gerdes, 1994:19; Muhtadi, et al., 2017:185). Etnomatematika mengungkapkan bahwa matematika dapat diidentifikasi dari kegiatan budaya dalam masyarakat tradisional maupun non tradisional (Dowling, 1991; Muhtadi, at al., 2019; Rosa \& Orey, 2007:15).

Beberapa studi tentang seni ukir Jepara sedikitnya telah mengungkap estetika dan filosofi dari seni ukir Jepara. Penelitian yang dilakukan oleh Rifandi dan Haryanto (2020) mengungkapkan bahwa pada relief ukir Mulyoharjo Jepara, bentuk estetis visual ditinjau dari unsur-unsur visual dan prinsip-prinsip estetis yang tersusun pada karya tersebut seperti irama, dominasi, keseimbangan, kesebandingan, keselarasan, dan kesatuan telah terpenuhi dan sebagian besar karya relief ukir Mulyoharjo memiliki kualitas bagus dalam estetika bentuk ukiran. Studi lainnya dilakukan oleh Suharto (2012) yang mengungkapkan bahwa seni ukir macan kurung merupakan ekspresi simbolik para perajin ukiran di Jepara atas tekanan hidup yang dirasakan pada masa itu dan merupakan pesan protes keterkungkungan budaya dalam masyarakat yang terjajah.

Beberapa penelitian yang dikemukakan sebelumnya mendeskripsikan seni ukir Jepara dari sudut pandang estetika dan filosofi secara terpisah. Di samping itu, adanya unfamiliar mathematics berkaitan dengan aktivitas mengukur dan membuat pola yang dilakukan oleh pengrajin ukiran Jepara belum banyak disadari oleh masyarakat luas. Kondisi ini tentunya menarik untuk dikaji dan diteliti lebih dalam, terutama dari segi filosofi dan matematis. Ditinjau dari segi filosofi, ada nilai-nilai dan ajaran yang dianut masyarakat dibalik sejarah seni ukir ukiran Jepara tersebut. Ditinjau dari segi matematis, ukiran tersebut dibuat melalui aktivitas, pola pikir, dan konsep matematis. Artikel ini bertujuan untuk membahas tentang filosofi pada seni ukir Jepara dan unsur matematis pada pembuatan seni ukir Jepara, serta hubungan antara kedua fokus kajian tersebut. 


\section{METODE PENELITIAN}

Penelitian ini bertujuan untuk mendeskripsikan filosofi berkaitan dengan nilai-nilai dan ajaran yang terdapat pada seni ukir Jepara, serta unsur matematis berkaitan dengan aktivitas dan konsep matematis pada proses pembuatan dan hasil produk ukiran Jepara. Oleh karena itu, metode yang digunakan dalam penelitian ini adalah metode deskriptif kualitatif dengan pendekatan etnografi, dimana penelitian kualitatif menghasilkan data yang bersifat deskriptif. Metode penelitian kualitatif dimaknai sebagai metode penelitian yang bersifat naturalistik karena penelitiannya dilakukan pada kondisi yang alamiah (natural setting). Sedangkan pendekatan etnografi adalah pendekatan kualitatif untuk menggambarkan, menganalisa, dan menafsirkan unsur-unsur dari sekelompok budaya, seperti pola perilaku, kepercayaan, dan bahasa yang berkembang dari suatu waktu ke waktu selanjutnya (Creswell, at al., 2016).

Sumber data dalam penelitian ini adalah pengrajin ukiran Jepara yang bertindak sebagai informan. Bentuk hasil ukiran Jepara dan aktivitas pengrajin dalam proses pembuatannya digali melalui teknik wawancara, observasi, dan dokumentasi. Dalam pengumpulan data, peneliti bertindak sebagai instrumen utama yang dilengkapi dengan pedoman wawancara, pedoman observasi, dan pedoman dokumentasi. Analisis data dilakukan melalui tahapan analisis menurut Miles dan Huberman (Sugiyono, 2019:246-252), yaitu: (1) reduksi data (data reduction) dilakukan dengan merangkum, menggolongkan data, dan membuang data yang tidak relevan, (2) penyajian data (data display) dilakukan dengan menyajikan data dalam bentuk uraian tentang seni ukir Jepara yang diperoleh dari pengumpulan data, dan (3) penarikan kesimpulan (conclusion drawing) yaitu data yang telah disajikan tersebut disimpulkan untuk mengungkap filosofi, unsur matematis, dan hubungan kedua fokus kajian tersebut pada seni ukir Jepara.

\section{HASIL DAN PEMBAHASAN}

Filosofi pada Seni Ukir Jepara. Filosofi pada seni ukir Jepara berkaitan dengan nilai, ajaran, atau kepercayaan yang dipegang oleh pengrajin ukiran Jepara pada khususnya dan masyarakat Jepara pada umumnya sebagai pedoman dalam melakukan aktivitas kehidupan dan menghasilkan karya seni ukir Jepara. Aktivitas kehidupan pengrajin ukiran Jepara tidak banyak berbeda dengan aktivitas keseharian masyarakat pada umumnya. Namun, pengrajin banyak menghabiskan waktu yang mereka miliki untuk menyelesaikan ukiran yang dipesan oleh pelanggan. Hal ini dikarenakan proses yang dilalui untuk menghasilkan produk ukiran mebel terbilang cukup rumit dan membutuhkan waktu yang sangat lama bahkan hingga waktu berbulan-bulan tergantung tingkat kerumitan ukiran mebel yang diinginkan pelanggan. Para pengrajin memulai pekerjaannya pada pukul 07.00 WIB di pagi hari, kemudian istirahat pada waktu dzuhur dan memulai pekerjaan kembali pukul 13.00 WIB hingga sore har sekitar pukul 17.00. Bahkan tidak jarang para pengrajin menghabiskan waktu malam mereka untuk menyelesaikan pekerjaannya. Hal ini dilakukan untuk mengejar tenggat waktu penyelesaian pesanan, dikarenakan beberapa pelanggan meminta agar hasil ukiran terselesaikan dengan waktu yang cepat.

Dengan banyaknya beban kerja yang dipikul oleh para pengrajin, dibutuhkan etos kerja, fokus, ketekunan, kesabaran, dan kesungguhan selama proses pembuatan ukiran. Hal ini dikarenakan pekerjaan ini membutuhkan keahlian yang baik dan waktu yang tidak dibilang sedikit. Dengan etos kerja yang dimiliki para pengrajin, mereka dapat mengoptimalkan hasil pekerjaannya hingga menghasilkan ukiran yang sesuai dengan apa yang diinginkan pelanggan dengan harapan para pelanggan merasa puas akan hasil kinerja mereka. Selain 
beberapa karakter tersebut, pengrajin juga merupakan seseorang yang taat dengan agamanya. Adanya nilai dan ajaran Islam untuk menjaga ibadahnya membuat pengrajin menjadi seorang Muslim yang taat beribadah dan memiliki keyakinan bahwa selama seorang Muslim menjaga hubungan baik dengan Allah SWT, maka Allah SWT juga akan mempermudah urusannya di dunia dan akhirat.

Nilai-nilai dan ajaran lainnya dapat digali dari bentuk motif dan corak ukirannya. Motif adalah sesuatu yang menjadi pokok atau unsur pokok sebuah ornamen (Depdiknas, 2008:1043; Sunarto, 2009). Sedangkan corak adalah bunga atau gambar-gambar yang berjenis-jenis warna (Depdiknas, 2008:291). Ornamen adalah hiasan atau lukisan yang digambar atau dipahat (Depdiknas, 2008:1094). Motif dan corak adalah unsur pokok yang terdapat pada ukiran. Tema atau ide dasar sebuah ornamen atau ukiran dapat dikenali melalui motif tersebut yang merupakan perwujudan atas bentuk-bentuk alam maupun bentuk-bentuk abstrak.

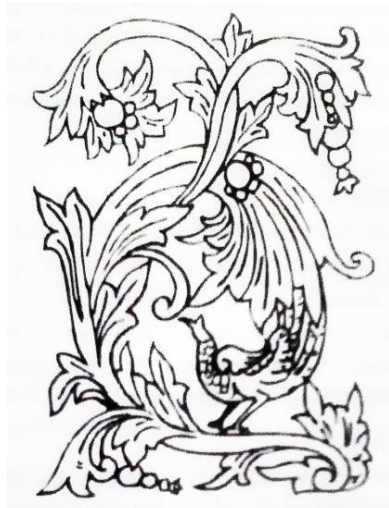

Gambar 1. Motif Ukiran Jepara (Soepratno, 2004)

Motif ukiran Jepara menggunakan motif tumbuhan yang dirangkai dengan motif hewan (Dalidjo \& Mulyadi, 1983:50). Ciri-ciri motif ukiran Jepara adalah daun pokok berbentuk relung, yang apabila dipotong melintang berbentuk prisma segitiga, daun-daunnya berbentuk segitiga, dan ukiran daunnya berbentuk miring (Soepratno, 2004:15). Motif ukiran Jepara didominasi oleh nuansa floratif atau perwujudan dari bentuk tumbuhtumbuhan dengan beberapa unsur yang melekat di dalamnya, yaitu daun, relung, buah, dan trubusan (Purnomo \& Kusumandyoko, 2017:570). Selain itu motif tumbuhan ini dipadukan dengan motif hewan, yaitu burung. Semua unsur yang membangun ukiran Jepara masingmasing memiliki makna tersendiri yang merupakan filosofi, ciri khas, dan identitas Kota Jepara.

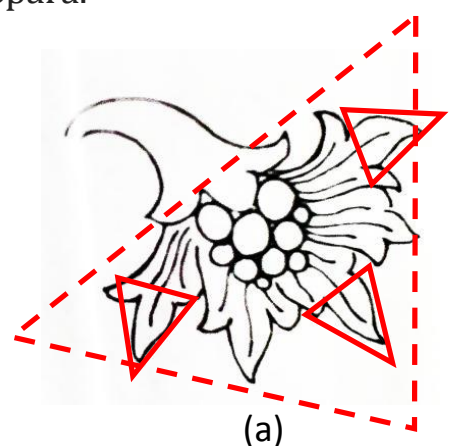

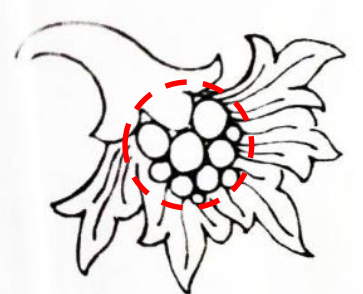

(b)

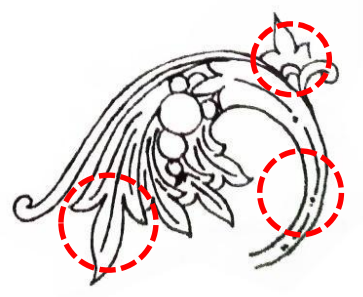

(c)

Gambar 2. (a) Bentuk Unsur Daun, (b) Bentuk Unsur Buah, (c) Bentuk Unsur Relung (Purnomo \& Kusumandyoko, 2017:570) 
Dalam nuansa floratif, unsur pertama pada motif ukiran Jepara yaitu daun jumbai. Daun pada ukiran Jepara memiliki bentuk segitiga dengan ujungnya lancip dan mempunyai corak merelung dan melingkar, yang memiliki makna berupa representasi hubungan religius antara manusia dengan Tuhan, maupun antar sesama manusia (Purnomo \& Kusumandyoko, 2017:570). Unsur kedua yaitu buah. Bentuk buah pada motif ukiran Jepara menyerupai buah anggur atau wuni, yaitu berbentuk bulatan-bulatan. Posisi buah pada motif ini cenderung tersusun sejajar ataupun bergerombol. Buah ini terdapat pada pertemuan relung daun pokok atau ujung relung yang dikelilingi daun-daun pokok. Unsur ketiga adalah relung atau lung. Unsur relung ini dapat ditemukan pada sebagian besar motif ukiran bernuansa floratif atau bertemakan tumbuhan. Unsur relung merupakan alur dari pangkal tumbuhan kepada daun. Relung ini memiliki makna yaitu membuat kesan luwes dan fleksibel pada ukiran (Purnomo \& Kusumandyoko, 2017:570). Pada bagian ini terdapat trubusan, yaitu bentuk ukiran daun yang tumbuh di tengah-tengah pangkal atau bagian bawah daun pokok. Pada ketiga unsur motif ukiran Jepara tersebut, terdapat makna nilai dan ajaran agama pada pecahan ukiran daun jumbai, yaitu terdapat tiga pecahan garis mengikuti bentuk daun sehingga tampak seperti sinar. Secara religius atau kepercayaan, sinar ini melambangkan cahaya sebagai simbol kehadiran Tuhan.

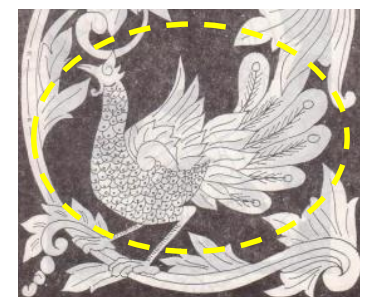

Gambar 3. Motif Unsur Burung Merak (Soepratno, 2004:15)

Di samping nilai agama, terdapat pula nilai moral seni ukir Jepara. Selain unsur bernuansa floratif, motif ukiran Jepara juga dipadukan dengan motif hewan, yaitu burung merak dengan sulur ubi jalar. Motif ini menggambarkan burung merak yang hinggap atau sedang terbang mengembangkan sayapnya mengisi sela-sela ukiran. Motif ini mempunyai makna yaitu kesesuaian dengan perilaku hidup sang pengrajin yang suka merantau dan hidup bebas terbang ke daerah lain untuk membangun karir (Gustami, 2000:193). Sedangkan sulur ubi jalar memvisualisasikan kesuburan dan melambangkan produk pekarangan yang apabila ditekuni dengan sungguh-sungguh meskipun dengan modal sedikit akan menghasilkan produk pangan yang mencukupi. Selain itu, daun jumbai merupakan perlambangan dari daun cengkeh dan sulur-sulur pada motif ukiran Jepara menggambarkan tumbuhan cengkeh yang tumbuh subur di Jepara dan memberikan kontribusi kuat terhadap perkembangan perekonomian masyarakat Jepara. Di samping itu, sulur-sulur yang rumit melambangkan ketekunan, keuletan, dan kesungguhan para pengrajin dalam mengerjakannya karena dibutuhkan keterampilan yang tinggi (Gustami, 2000:194).

Seni ukir Jepara mengandung nilai-nilai berkaitan dengan filosofi, diantaranya nilai agama, nilai moral, dan nilai budaya. Nilai agama terkandung pada unsur daun jumbai berbentuk segitiga. Segitiga melambangkan hubungan antara manusia dengan Tuhan, dan manusia dengan manusia lainnya. Dalam hubungannya dengan Tuhan, manusia memiliki kewajibankewajiban untuk melaksanakan perintah Tuhan dan menjauhi larangan-Nya, sedangkan dari Tuhan, manusia akan mendapat rahmat yang tak terhingga. Dalam hubungannya dengan sesamanya, manusia berperan baik sebagai warga masyarakat maupun warga negara. Misalnya sebagai warga masyarakat manusia menghormati sesamanya, maka mereka akan menghormati manusia itu sendiri. Sedangkan sebagai warga negara apabila manusia mentaati perundang-undangan dengan membayar pajak, maka hak yang diterima 
adalah pembangunan infrastruktur. Selain hubungan segitiga itu, nilai agama juga terkandung dalam pecahan pada ukiran daun jumbai menyerupai sinar, yaitu melambangkan bahwa cahaya merupakan simbol kehadiran Tuhan, dan sinar garis cahaya tersebut menyebar ke segala arah.

Nilai moral pada seni ukir Jepara ini dapat dilihat dari makna filosofis pada unsur sulursulur motif ukiran yang melambangkan kepribadian yang baik, yaitu ketekunan, keuletan, dan kesungguhan para pengrajin dalam membuat seni ukir Jepara. Sedangkan nilai budaya pada seni ukir Jepara dapat dilihat dari keteguhan masyarakat Jepara untuk mengembangkan dan melestarikan seni ukir sebagai ciri khas kotanya. Keteguhan dalam mengembangkan seni ukir Jepara ini telah membudaya sejak zaman Raden Ajeng Kartini hingga masa modern saat ini dapat ditemui banyaknya sentra industri seni ukir Jepara meliputi mebel maupun ukiran Jepara. Perkembangan ini meningkatkan citra Jepara sebagai "The World Carving Center", sehingga seni ukir Jepara ini telah menjadi budaya yang dimiliki oleh masyarakat Jepara dengan segala ciri khas dan filosofinya.

Aktivitas dan Konsep Matematis pada Pembuatan Seni Ukir Jepara. Unsur matematis pada seni ukir Jepara dideskripsikan berdasarkan dua kajian, yaitu aktivitas matematis dan konsep matematis. Aktivitas matematis dalam penelitian ini mengacu pada aktivitas atau kegiatan yang dilandasi oleh cara berpikir yang dilakukan oleh pengrajin ukiran dalam proses pembuatan ukiran Jepara, dimana kegiatan-kegiatan atau cara berpikir tersebut berkaitan dengan matematika. Sedangkan konsep matematis dalam penelitian ini mengacu pada gagasan atau ide matematis mengenai beberapa topik atau materi yang berhubungan dengan matematika.

Beberapa aktivitas matematis yang dilakukan oleh pengrajin ukiran Jepara meliputi aktivitas menghitung (counting), melokasikan (locating), mengukur (measuring), dan merancang (designing). Aktivitas menghitung (counting) menghasilkan beberapa ide matematis seperti angka, metode perhitungan, sistem bilangan, pola bilangan, metode numerik, statistika, dan sebagainya (Bishop, 1997). Aktivitas menghitung yang dilakukan pengrajin dalam pembuatan ukiran mebel Jepara terintegrasi dalam beberapa kegiatan, yaitu menghitung perkiraan lamanya waktu penyelesaian ukiran sesuai permintaan pelanggan, menghitung banyaknya biaya investasi pengadaan peralatan yang dibutuhkan, dan menghitung pembagian penghasilan kepada para pekerja. Aktivitas menghitung lamanya waktu penyelesaian ukiran dilakukan dengan memperkirakan tingkat kesulitan tiap-tiap bagian ukiran yang akan dikerjakan kemudian dibagi dengan banyaknya jumlah pengrajin, sehingga semakin banyak jumlah pengrajin yang mengerjakan ukiran tersebut, maka akan semakin cepat ukiran tersebut dapat diselesaikan. Aktivitas menghitung biaya investasi peralatan dilakukan pengrajin dengan menjumlahkan seluruh biaya pembelian alat-alat yang dibutuhkan untuk pembuatan ukiran Jepara. Sedangkan aktivitas menghitung pembagian penghasilan dilakukan dengan menghitung pendapatan yang dihasilkan dalam satu kali pesanan ukiran mebel dibagi dengan jumlah pengrajin.

Aktivitas melokasikan (locating) berkaitan dengan menemukan suatu jalan, menempatkan sebuah objek, dan menentukan hubungan suatu objek dengan objek yang lainnya, sehingga menghasilkan dimensi, sumbu, koordinat kartesius, dan sebagainya (Bishop, 1997). Aktivitas melokasikan yang dilakukan pengrajin dalam pembuatan ukiran mebel Jepara terintegrasi dalam beberapa kegiatan, yaitu menempatkan objek bunga, buah, dan daun dalam satu motif ukiran, serta menentukan hubungan antara objek bunga, buah, dan daun dalam satu motif ukiran. Aktivitas menempatkan dan menghubungkan antara beberapa objek dalam motif ukiran ini dilakukan dengan menentukan posisi atau letak bunga, buah, dan daun yang baik agar motif ukiran terlihat padu, indah dan luwes. Sehingga melalui 
aktivitas ini melahirkan pula beberapa ide matematis yaitu dimensi seperti ukuran, titik, dan garis, serta sumbu koordinat seperti sumbu $x$ dan sumbu $y$ pada satu motif ukiran yang akan dibahas pada pembahasan selanjutnya mengenai geometri transformasi.

Aktivitas mengukur (measuring) melibatkan beragam kemampuan seperti halnya membilang, tetapi juga melibatkan perkiraan, pendekatan, dan evaluasi (Bishop, 1997). Aktivitas mengukur yang dilakukan pengrajin dalam pembuatan ukiran mebel Jepara terintegrasi dalam aktivitas mengukur panjang, lebar, dan tebal kayu yang dibutuhkan. Mengukur panjang, lebar, dan tebal kayu dilakukan dengan menggunakan meteran dan melibatkan perkiraan (estimasi), yaitu memperkirakan ukuran mebel ukiran Jepara disesuaikan dengan permintaan pelanggan dan kondisi tempat yang akan dipasang ukiran mebel tersebut. Sebagai contoh, pengrajin memperkirakan untuk ukiran mebel kursi ruang tamu, jika ruangan pelanggan berukuran $3 \times 3$ meter maka panjang kursi sikunya berukuran sekitar 2 meter hingga 2,5 meter supaya kursi tersebut cukup untuk ditempatkan di ruangan tersebut, sehingga panjang kayu yang dibutuhkan sekitar 2 meter hingga 2,5 meter. Kemudian untuk tebal kayu diperkirakan umumnya sekitar 1,5 hingga 2,5 $\mathrm{cm}$.

Aktivitas matematika yang terakhir adalah aktivitas merancang (designing). Aktivitas merancang berkaitan dengan pembuatan pola dalam menciptakan objek-objek, sehingga mengembangkan beberapa kemampuan seperti menggambar dan berimajinasi (Bishop, 1997). Aktivitas merancang yang dilakukan pengrajin dalam pembuatan ukiran mebel Jepara terintegrasi dalam pembuatan pola motif ukiran, dimana dalam aktivitas ini pengrajin menggambar pola-pola secara manual pada kertas yang nantinya akan diterapkan pada kayu.

Selain aktivitas matematis, terdapat pula beberapa konsep matematis yang diterapkan pengrajin ukiran Jepara. Konsep matematis dapat ditemukan selama proses pembuatan hingga hasil ukirannya terselesaikan. Beberapa konsep matematis ini diantaranya adalah konsep titik dan garis, sudut dan kemiringan (gradien), geometri bangun datar, bangun ruang, kesebangunan dan kekongruenan, dan geometri transformasi.

Titik dan garis dalam kajian geometri dapat dideskripsikan tetapi tidak dapat didefinisikan (Alexander \& Koeberlein, 2020:10). Sebuah titik disimbolkan dengan noktah (.) memiliki tempat tetapi tidak memiliki ukuran, sehingga diartikan bahwa titik tidak memiliki dimensi, sedangkan garis terbentuk dari himpunan titik-titik yang banyaknya tak terhingga. Konsep titik dan garis pada seni ukir Jepara dapat diidentifikasi dari bentuk motif dan corak ukirannya. Ukiran atau pahatan yang dibentuk pada seni ukir Jepara melahirkan garis-garis yang membentuk sebuah objek. Garis tersebut ditentukan oleh dua buah titik atau lebih yang meluas ke dalam dua arah garis (Downing, 2009:191). Konsep titik dan garis diterapkan pada ukiran Jepara yang terlihat pada motif ukirannya, dimana ornamenornamen motif ukiran berupa garis, seperti garis lurus, garis patah, garis miring, garis sejajar, garis lengkung, dan sebagainya. Unsur garis pada ukiran Jepara didominasi oleh garis lengkung seperti terdapat pada bagian sulur-sulur berbentuk relung. Konsep titik dan garis ini juga tidak lepas dari proses pembuatan ukiran, dimana pada tahap awal pengrajin membuat pola motif ukiran yang merupakan kombinasi garis-garis lengkungan. Untuk membuat pola ini, pengrajin harus menentukan beberapa titik untuk menempatkan objek yang nantinya akan digambar dengan menambahkan garis-garis untuk menghubungkannya, sehingga menghasilkan motif yang indah dan padu. 


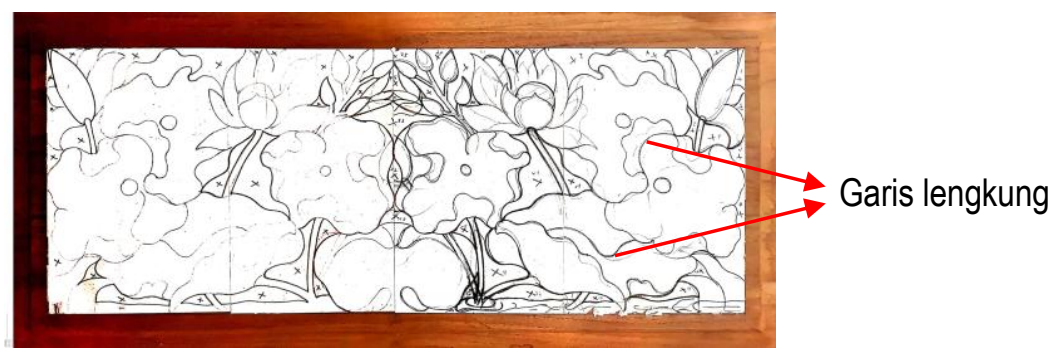

Gambar 4. Konsep garis pada pola motif ukiran Jepara

Konsep sudut dan kemiringan (gradien) juga terdapat pada proses pembuatan seni ukir Jepara. Sudut didefinisikan sebagai pertemuan antara dua sinar garis yang mempunyai titik pangkal yang sama (Alexander \& Koeberlein, 2020:31). Sedangkan gradien atau kemiringan adalah tingkat kemiringan garis atau perbandingan antara perpindahan vertikal terhadap perpindahan horizontal (Agus, 2008:43; Dudeja, Madhavi, \& Ali, 2014). Konsep gradien dalam pembuatan seni ukir Jepara terdapat pada posisi penempatan kemiringan pisau pahat yang ditempatkan pada permukaan kayu, sehingga ketika pisau pahat terdorong oleh palu maka akan terbentuk pahatan atau ukiran dengan kedalaman dan kemiringan tertentu. Dengan penempatan pisau pahat berdasarkan kemiringan tertentu ini menghasilkan konsep sudut, yaitu pertemuan antara sinar garis pisau pahat dengan sinar garis permukaan kayu pada sumbu $x$ (horizontal) yang mempunyai titik pangkal yang sama. Besar sudut ini ternyata mempengaruhi hasil ukiran, dimana untuk menghasilkan ukiran yang lebih dalam maka diperlukan sudut yang lebih besar.
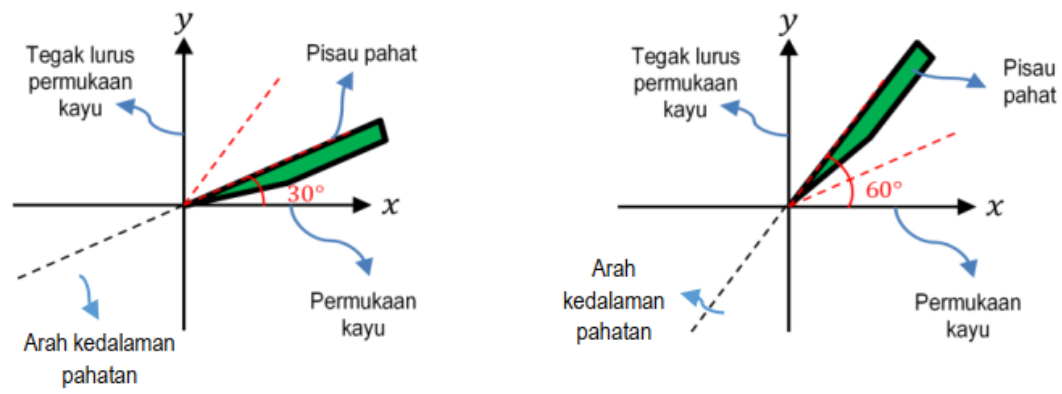

Gambar 5. Ilustrasi konsep kemiringan (gradien) dan sudut pada proses pembuatan ukiran Jepara

Di samping itu, ada pula konsep geometri bangun datar pada hasil ukiran Jepara. Seperti yang telah dibahas sebelumnya mengenai motif seni ukir Jepara, terdapat unsur-unsur dari motif yang menyerupai bentuk bangun datar, diantaranya adalah daun jumbai berbentuk segitiga yang ditandai dengan ujungnya berbentuk lancip dan buah berbentuk lingkaran. Selain itu pada motif lainnya juga terdapat unsur daun berbentuk segitiga yang disusun sedemikian rupa sehingga motif menjadi indah, padu, dan simetris.
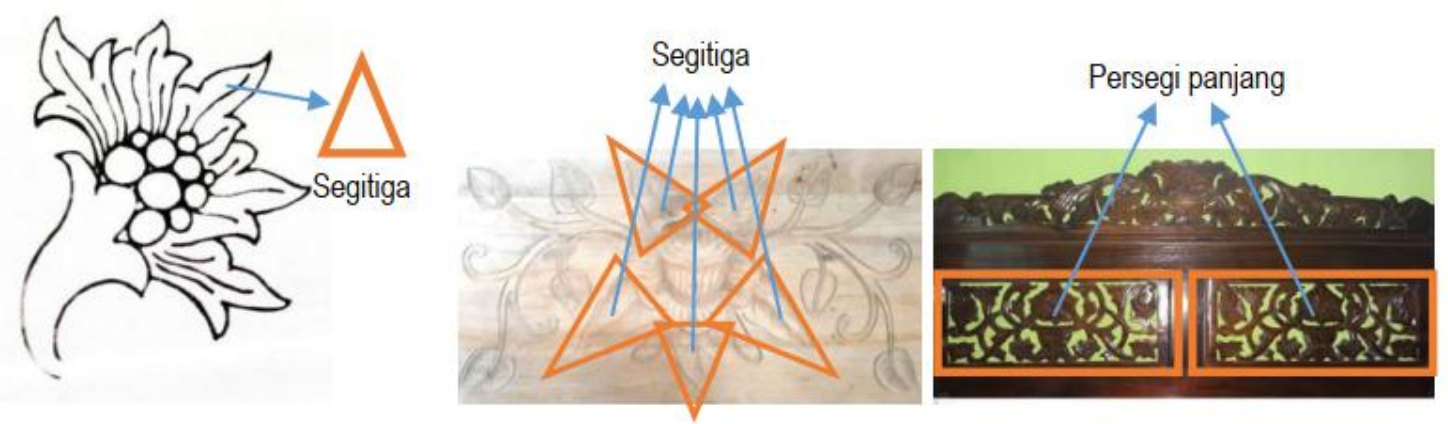

Gambar 6. Konsep geometri bangun datar pada motif ukiran Jepara 
Selain konsep geometri bangun datar segitiga dan persegi panjang, ada pula konsep bangun lingkaran dalam motif ukiran Jepara. Lingkaran adalah salah satu bentuk geometris berupa kurva tertutup sederhana yang membagi bidang menjadi dua bagian, yaitu bagian dalam lingkaran dan bagian luar lingkaran (Kemendikbud, 2017:58). Bangun lingkaran menjadi salah satu bentuk geometri datar yang sering dijumpai dan dimanfaatkan oleh manusia dalam aktivitas di berbagai bidang kehidupan sehari-hari, seperti olahraga, arsitektur, seni, teknologi, dan sebagainya. Lingkaran ini memiliki ciri-ciri yaitu bentuk kurva tertutup dimana seluruh titik yang ada pada lingkaran memiliki jarak yang sama terhadap suatu titik yang disebut titik pusat lingkaran atau jari-jari. Sebagai salah satu bentuk geometris, selain jari-jari, juga terdapat beberapa unsur lainnya yang dimiliki lingkaran, diantaranya adalah diameter, busur, tali busur, apotema, juring, tembereng, sudut pusat, dan sudut keliling. Unsur- unsur ini juga dimiliki pada motif ukiran Jepara yang berbentuk bangun lingkaran. Pengrajin ukiran Jepara menerapkan konsep lingkaran untuk memperindah variasi motif ukiran yang dipadukan dengan beberapa bentuk geometris lainnya.
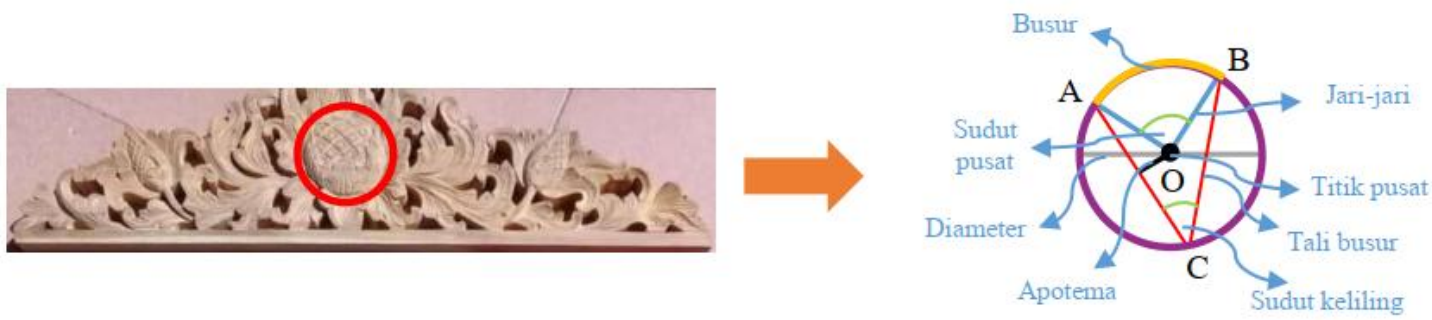

Gambar 7. Konsep bangun lingkaran pada motif ukiran Jepara

Selain konsep bangun datar, ada pula konsep bangun ruang pada seni ukir Jepara. Konsep bangun ruang pada seni ukir Jepara dapat dilihat dari media atau bahan pembuatan ukiran. Bahan untuk membuat ukiran Jepara menggunakan media papan kayu berbentuk bangun ruang balok. Balok kayu tersebut memiliki panjang, lebar, dan tinggi. Selain itu terdapat unsur sisi, rusuk, dan titik sudut. Balok kayu tersebut dalam prosesnya dipahat dengan menggunakan pisau pahat hingga membentuk sebuah motif.

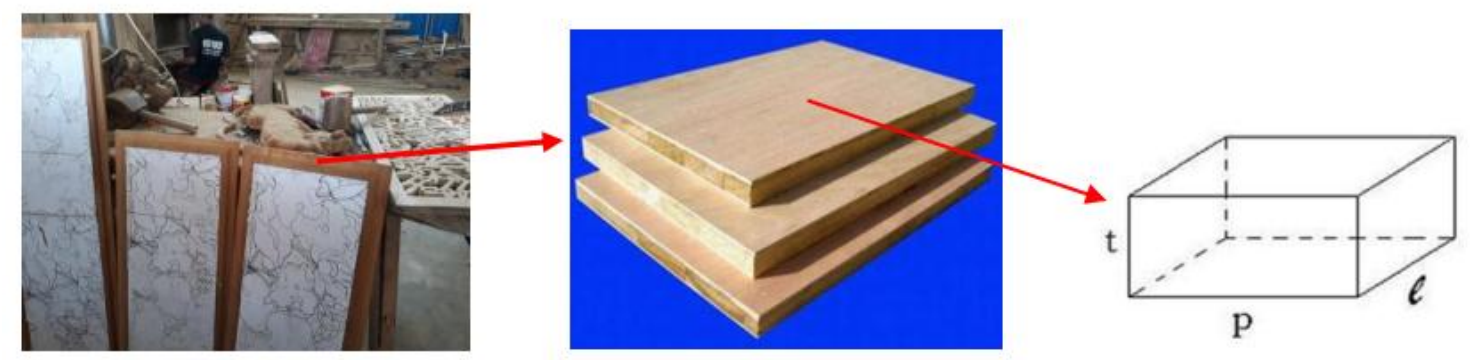

Gambar 8. Konsep bangun ruang pada bahan atau media pembuatan ukiran Jepara

Berkaitan dengan bangun datar, ada pula konsep kekongruenan yang terdapat pada ukiran Jepara. Dua buah bangun datar disebut kongruen jika memiliki bentuk dan ukuran yang sama (Kemendikbud, 2018:349). Konsep kekongruenan ini terintegrasi pada pembuatan pola dan corak motif daun segitiga pada ukiran Jepara, dimana untuk menghasilkan motif yang indah pengrajin menyatukan beberapa corak daun berbentuk segitiga yang kongruen untuk dipadukan. 

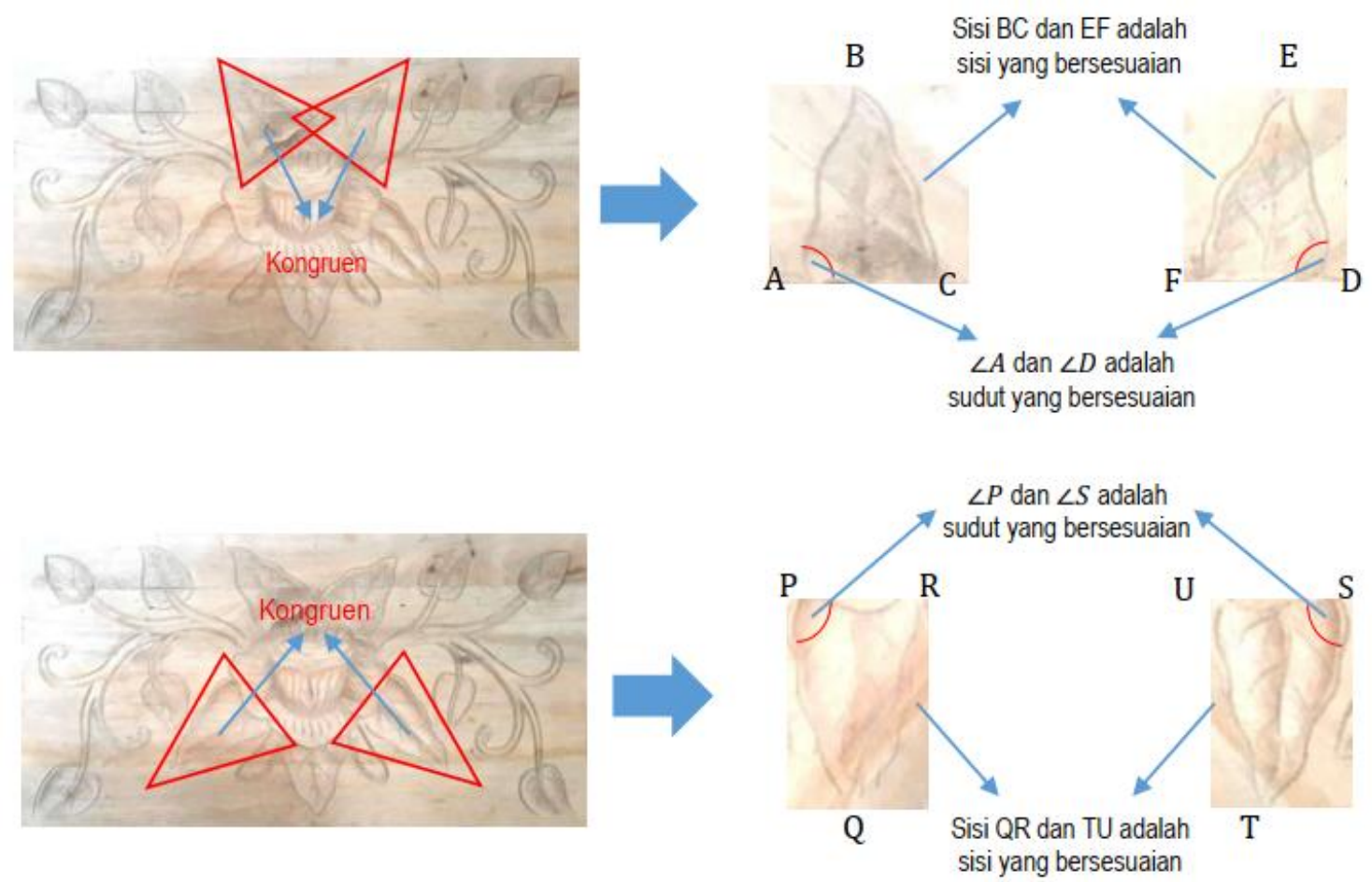

Gambar 9. Konsep kekongruenan pada motif ukiran Jepara

Dua bangun datar dikatakan kongruen jika memenuhi dua syarat, yaitu sisi-sisi yang bersesuaian sama panjang dan sudut-sudut yang bersesuaian sama besar. Berdasarkan gambar 8, terlihat bahwa dua buah segitiga, yaitu $\triangle A B C$ dan $\triangle D E F$ kongruen, dikarenakan terdapat sisi-sisi yang bersesuaian sama panjang, yaitu: $A B=D E, A C=D F$, dan $B C=E F$, serta terdapat sudut-sudut yang bersesuaian sama besar, yaitu: $\angle A=\angle D, \angle B=\angle E$, dan $\angle C=\angle F$. Selain itu, terdapat dua buah segitiga lainnya yang kongruen, yaitu $\triangle P Q R$ dan $\triangle S T U$, dikarenakan terdapat sisi-sisi yang bersesuaian sama panjang, yaitu: $P Q=S T, P R=$ $S U$, dan $Q R=T U$, serta terdapat sudut-sudut yang bersesuaian sama besar, yaitu: $\angle P=$ $\angle S, \angle Q=\angle T$, dan $\angle R=\angle U$. Dengan demikian, karena $\triangle A B C$ dan $\triangle D E F$ memenuhi syarat kekongruenan, maka $\triangle A B C$ dan $\triangle D E F$ kongruen, dinotasikan dengan $\triangle A B C \cong \triangle D E F$. Kemudian, karena $\triangle P Q R$ dan $\triangle S T U$ memenuhi syarat kekongruenan, maka $\triangle P Q R$ dan $\triangle S T U$ juga kongruen, dinotasikan dengan $\triangle P Q R \cong \triangle S T U$. Konsep kekongruenan ini terintegrasi dalam cara berpikir pengrajin ukiran dalam membuat pola dan menghasilkan corak serupa yang memiliki ukuran yang sama, sehingga motif ukiran menjadi lebih rapi dan indah.

Konsep matematika terakhir yang terdapat pada seni ukir Jepara yaitu geometri transformasi. Kurniasih \& Handayani (2017) mengemukakan bahwa geometri transformasi adalah pemetaan satu-satu atau menghubungkan suatu bilangan real dengan bilangan real lainnya, yang terdiri dari beberapa sifat, yaitu refleksi, rotasi, translasi, dan dilatasi. Sifat yang pertama adalah refleksi (pencerminan) yaitu bagian dari transformasi yang memindahkan suatu titik pada bangun geometri dengan menggunakan sifat benda dan bayangan pada cermin datar (Kurniasih \& Handayani, 2017). Sifat refleksi diterapkan oleh pengrajin dalam pembuatan pola motif ukiran, dimana untuk menghasilkan motif simetris yang indah maka dibutuhkan keseimbangan pola antara posisi kanan kiri atau atas bawah. 


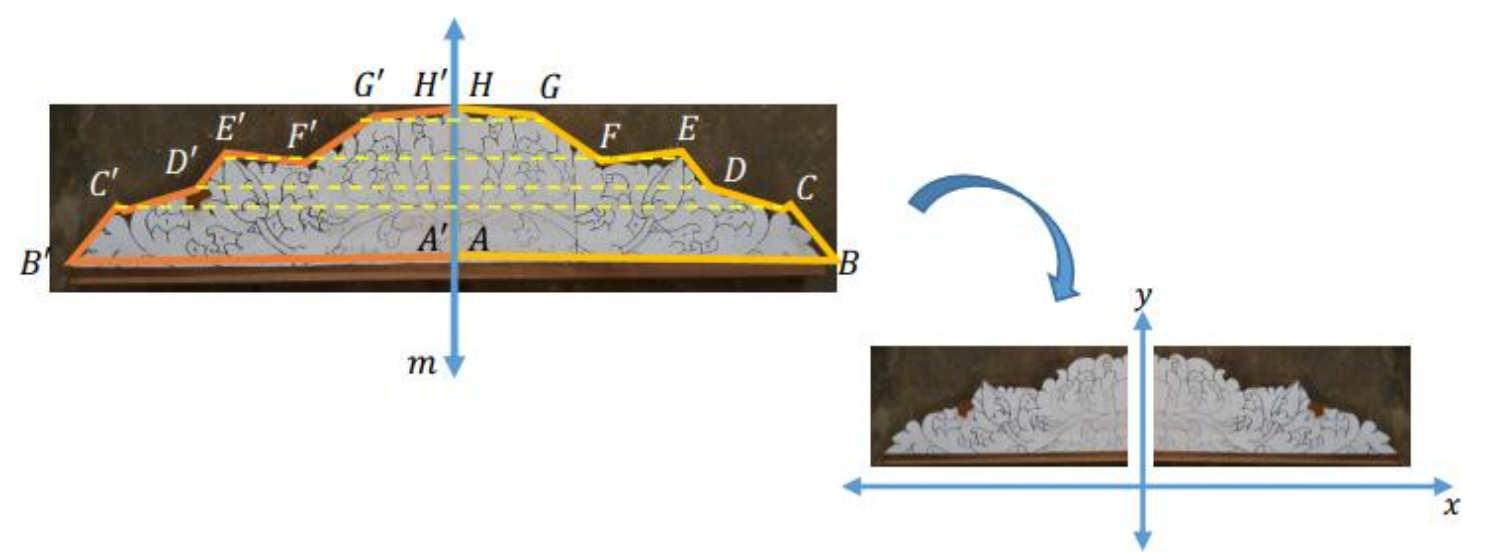

Gambar 10. Konsep refleksi (pencerminan) pada pembuatan ukiran Jepara

Pada gambar di atas menunjukkan bangun $A B C D E F G H$ pada motif ukiran Jepara yang direfleksikan (dicerminkan) terhadap garis $m$ yang disebut garis refleksi, sehingga menghasilkan bayangan $A^{\prime} B^{\prime} C^{\prime} D^{\prime} E^{\prime} F^{\prime} G^{\prime} H^{\prime}$. Karena titik $A$ dan $H$ terletak pada garis refleksi, maka titik awal dan bayangannya berada di titik yang sama. Sehingga jarak antara titik $A$ terhadap garis $m$ sama dengan jarak titik $A^{\prime}$ terhadap garis $m$, begitu pula jarak antara titik $H$ terhadap garis $m$ sama dengan jarak titik $H^{\prime}$ terhadap garis $m$. Hal ini juga berlaku terhadap titik lainnya, yaitu jarak $B m=m B^{\prime}, C m=m C^{\prime}, D m=m D^{\prime}, E m=m E^{\prime}, F m=$ $m F^{\prime}, G m=m G^{\prime}$, dan $H m=m H^{\prime}$. Dengan menggunakan konsep refleksi ini, pengrajin dapat menggambar dan menghasilkan pola motif ukiran yang simetris.

Sifat yang kedua adalah rotasi (perputaran), yaitu bentuk transformasi yang memutar setiap titik pada objek gambar hingga sudut dan arah tertentu (sudut rotasi) terhadap titik yang tetap yang disebut pusat rotasi (Kemendikbud, 2018:281). Sifat rotasi diterapkan oleh pengrajin dalam pembuatan pola motif ukiran, dimana untuk menghasilkan motif yang padu dibutuhkan beberapa paduan corak yang kongruen dengan berbagai macam posisi atau arah perputaran. Untuk menciptakan keberagaman posisi, pengrajin perlu melakukan pemutaran terhadap suatu corak utama sehingga menghasilkan beberapa corak dengan arah posisi yang berbeda.
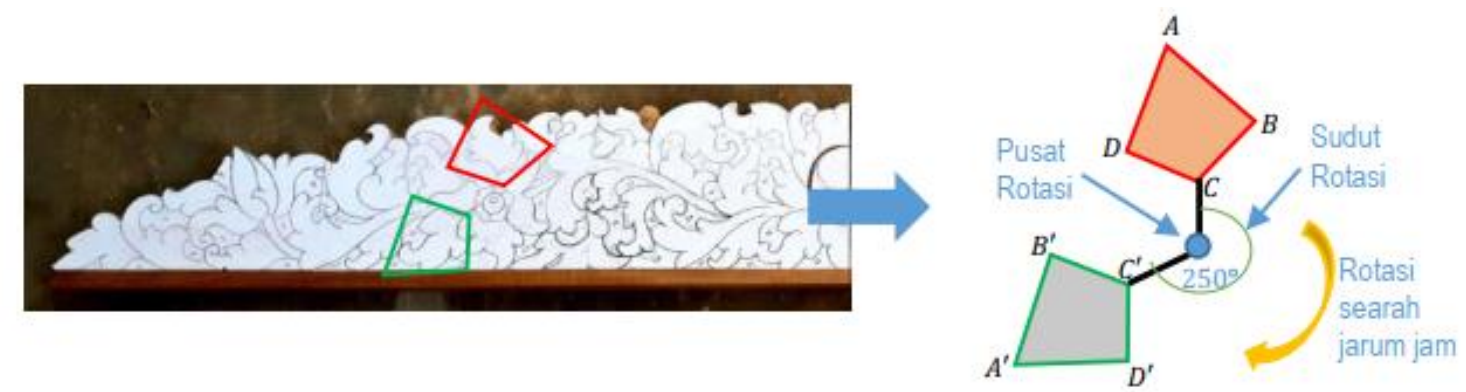

Gambar 11. Konsep rotasi (perputaran) pada pembuatan ukiran Jepara

Sifat yang ketiga adalah translasi (pergeseran), yaitu suatu jenis transformasi geometri yang bertujuan untuk memindahkan seluruh titik pada suatu bangun dengan jarak dan arah yang sama (Kemendikbud, 2008). Sifat translasi pada seni ukir Jepara ini diterapkan oleh pengrajin dalam pembuatan motif ukiran, dimana pengrajin membuat beberapa motif yang disusun berdampingan dan masing-masing motif tersebut memiliki unsur atau ornamen yang sama persis, sehingga menghasilkan motif yang padu dan rapi. Untuk menciptakan kerapihan dari perpaduan motif yang sama tersebut, pengrajin perlu memindahkan semua titik pada motif yang satu pada motif yang lainnya dengan jarak dan arah yang sama. 

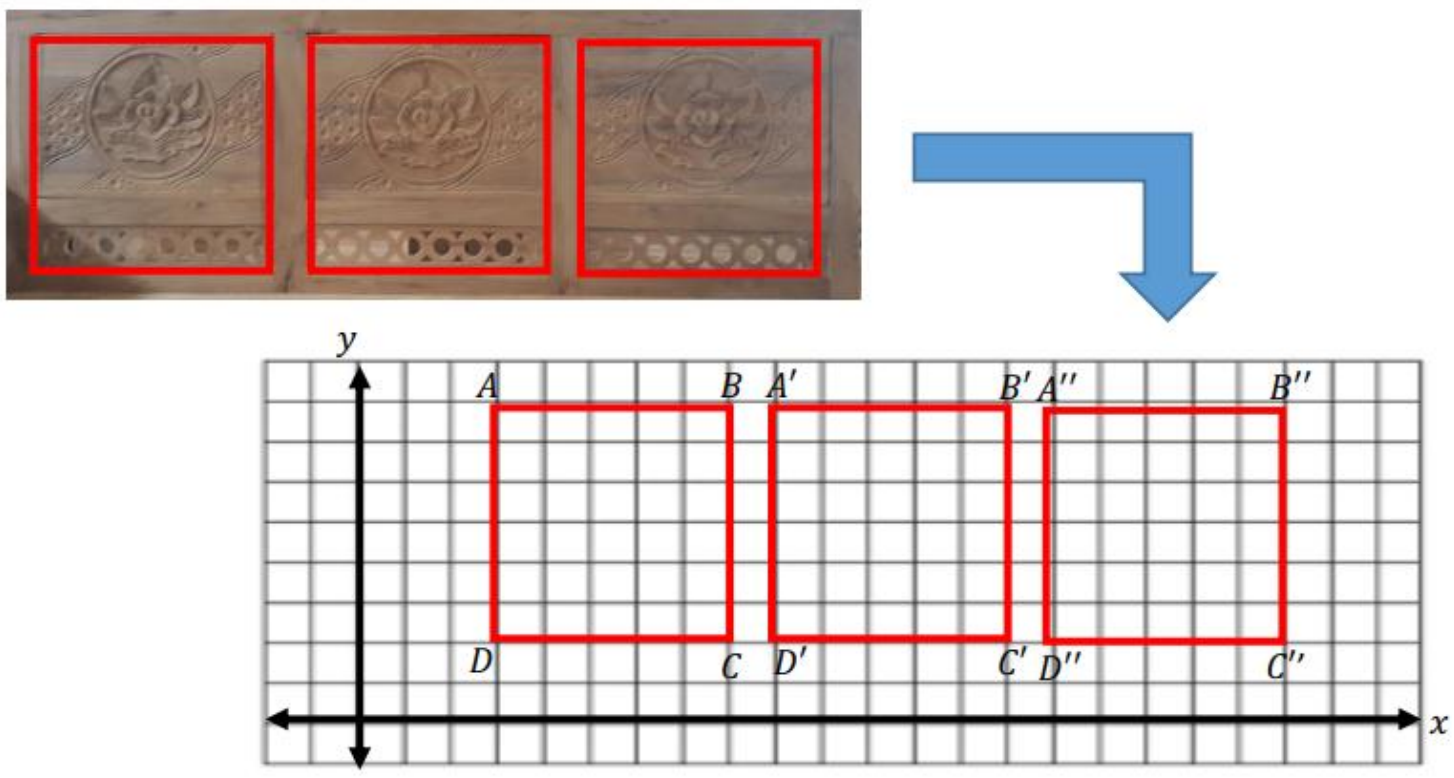

Gambar 12. Konsep Translasi pada Motif Ukiran Jepara

Pada gambar di atas menunjukkan bangun $A B C D$ yang ditranslasikan sejauh 6 satuan ke kanan sehingga menghasilkan koordinat bayangan $A^{\prime} B^{\prime} C^{\prime} D^{\prime}$. Kemudian bangun hasil bayangan $A^{\prime} B^{\prime} C^{\prime} D^{\prime}$ ditranslasikan kembali sejauh 6 satuan ke kanan sehingga menghasilkan koordinat bayangan $A^{\prime \prime} B^{\prime \prime} C^{\prime \prime} D^{\prime \prime}$. Dengan demikian panjang $A A^{\prime}=B B^{\prime}=C C^{\prime}=D D^{\prime}=$ $A^{\prime} A^{\prime \prime}=B^{\prime} B^{\prime \prime}=C^{\prime} C^{\prime \prime}=D^{\prime} D^{\prime \prime}$.

Hubungan antara Filosofi dan Unsur Matematis pada Seni Ukir Jepara. Filosofi yang mengacu pada makna tersirat pada ukiran Jepara yang dipegang teguh dan dijunjung tinggi oleh masyarakat Jepara khususnya pengrajin ukiran Jepara dalam menghasilkan karya seni bernilai estetika ini menjadi hal yang menarik dan tak lepas dari sejarah panjang perkembangan seni ukir Jepara. Filosofi mengenai ajaran, nilai, dan kepercayaan yang berkaitan dengan agama, moral, dan budaya masyarakat Jepara menjadi landasan dan pedoman hidup pengrajin ukiran Jepara dan sekaligus melatarbelakangi adanya seni ukir tersebut. Keberadaan filosofi pada seni ukir Jepara ini tidak semerta-merta berdiri sendiri dalam mendukung terciptanya seni ukir bernilai estetis, melainkan didukung oleh disiplin ilmu lainnya, yaitu ilmu matematika.

Matematika menjadi suatu disiplin ilmu yang tidak terlepas dari kehidupan manusia, salah satunya adalah berperan penting dalam aktivitas manusia untuk membuat ukiran. Hal ini berkaitan dengan definisi mengenai matematika merupakan ilmu tentang pola dan hubungan, pola pikir, suatu seni, bahasa, atau alat (Fahrurrozi \& Hamdi, 2017:3; Reys, 1984). Definisi lainnya menjelaskan bahwa matematika meliputi berbagai macam pengukuran, perhitungan, dan penggambaran suatu bentuk objek (Nasution, 1980; Sukasno, 2012:108). Pola pikir matematika mengenai pengukuran, perhitungan, dan penggambaran suatu bentuk objek ini dimiliki oleh diri pribadi pengrajin ukiran Jepara. Pola pikir ini melandasi adanya keterampilan mengukir yang dimiliki pengrajin ukiran Jepara. Sehingga dengan pola pikir matematika yang mereka miliki, mereka dapat mengaplikasikannya pada tahap-tahap dan proses pembuatan ukiran Jepara, seperti aktivitas mengukur, menghitung, melokasikan, dan membuat pola. Terlebih lagi beberapa unsur matematika seperti konsep garis, sudut, kemiringan, geometri bangun datar, bangun ruang, kekongruenan, dan transformasi geometri juga tanpa sadar telah diterapkan para 
pengrajin untuk menyempurnakan hasil karyanya hingga menghasilkan ukiran Jepara dengan motif yang indah dan padu.

Keberadaan filosofi dan unsur matematis yang tertanam dalam pola pikir pengrajin ukiran Jepara ini secara tidak langsung menjadi dua hal yang terkait dan tidak lepas dari seni ukir Jepara, dimana kedua disiplin ilmu ini memiliki peran yang mendukung terciptanya karya seni ukir Jepara yang indah. Filosofi berperan sebagai landasan dan pedoman yang melatarbelakangi langkah awal adanya ukiran Jepara, sedangkan unsur matematis menjadi ilmu yang berperan dalam proses penciptaan ukiran Jepara tersebut. Keduanya secara bersama-sama ada dan berperan penting mendukung keberadaan seni ukir Jepara dengan beragam nilai-nilai yang terkandung di dalamnya.

\section{SIMPULAN}

Berdasarkan hasil penelitian mengenai studi etnomatematika pada seni ukir Jepara, dapat disimpulkan beberapa hal berikut: (1) seni ukir Jepara kaya akan filosofi, diantaranya adalah nilai, ajaran, dan kepercayaan berkaitan dengan agama, moral, dan budaya yang melatarbelakangi adanya ukiran Jepara tersebut, (2) unsur matematika terintegrasi dalam pola pikir pengrajin dan teraplikasi dalam pembuatan seni ukir Jepara, diantaranya adalah aktivitas matematis yang berkaitan dengan aktivitas menghitung (counting), melokasikan (locating), mengukur (measuring), dan merancang (designing), serta konsep matematis yang berkaitan dengan titik, garis, sudut, kemiringan (gradien), geometri bangun datar, lingkaran, geometri bangun ruang, kekongruenan, dan transformasi geometri refleksi dan rotasi, (3) filosofi dan unsur matematis secara bersama-sama berperan penting dan mendukung keberadaan seni ukir Jepara yang kaya akan nilai dan ajaran.

\section{DAFTAR RUJUKAN}

Agus, N.A. (2008). Mudah Belajar Matematika: untuk Kelas VIII Sekolah Menengah Pertama/Madrasah Tsanawiyah. Jakarta: Pusat Perbukuan Departemen Pendidikan Nasional.

Alexander, D.C., \& Koeberlein, G.M. (2020). Elementary Geometry for College Students (7th ed). Boston, MA, USA: Cengage Learning.

Bishop, A. J. (1997). The Relationship between Mathematics Education and Culture. In Opening address Delivered of Iranian Mathematics Education Conference. Kermannshah, Iran. Retrieved from https://www.researchgate.net/publication/255590052

Creswell, J.w., Pancasari, R.K. (Trans.), \& Fawaid A. (2016). Research Design: Pendekatan Kualitatif, Kuantitatif, dan Mixed (4th ed). Yogyakarta: Pustaka Pelajar.

D'Ambrosio, U. (1985). Ethnomathematics and its Place in the History and Pedagogy of Mathematics. For the learning of Mathematics, 5(1), 44-48. Retrieved from https://www.jstor.org/stable/ 40247876

Dalidjo, D. \& Mulyadi. (1983). Pengenalan Ragam Hias Jawa IA. Departemen Pendidikan dan Kebudayaan.

Departemen Pendidikan Nasional. (2008). Kamus Besar Bahasa Indonesia. Jakarta: Pusat Bahasa. 
Dowling, P. (1991). The Contextualizing of mathematics: Towards a Theoretical Map. In M. Harris (Ed.), Schools, Mathematics, and Work (pp. 93-120). London, England: Falmer Press.

Downing, D. (2009). Dictionary of Mathematics Term (3rd ed). New York: Barron's Educational Series.

Dudeja, V., Madhavi, V., \& Ali, M. (2014). Jelajah Matematika 1 SMP Kelas VII (2nd ed). Jakarta: Yudhistira.

Fahrurrozi, \& Hamdi, S. (2017). Metode Pembelajaran Matematika. Universitas Hamzanwadi Press.

Gerdes, P. (1994). Reflection on Ethnomatematics. For the Learning of Mathematiccs, 14(2), 19-21. Retrieved from https://flmjournal.org/Articles/1CC7C4A1B63D66ADF10C6D5AE98E58. pdf

Gustami, S.P. (2000). Seni Kerajinan Mebel Ukir Jepara: Kajian Estetik Melalui Pendekatan Multidisiplin. Yogyakarta: Kanisius.

Kementerian Pendidikan dan Kebudayaan. (2017). Matematika Kelas VIII SMP/MTS Semester 2 (Rev ed). Jakarta: Pusat Kurikulum dan Perbukuan, Balitbang, Kemendikbud.

Kementerian Pendidikan dan Kebudayaan. (2018). Buku Guru Matematika SMP/MTS Kelas IX (Rev ed). Jakarta: Pusat Kurikulum dan Perbukuan, Balitbang, Kemendikbud.

Kurniasih, M.D., \& Handayani, I. (2017). Tangkas Geometri Transformasi: Cepat Tepat Menguasai Geometri Transformasi. Fakultas Keguruan dan Ilmu Pendidikan, Universitas Muhammadiyah Prof. Dr. Hamka.

Muhtadi, D., Sukirwan, Warsito, \& Prahmana, R.C.I. (2017). Sundanese Ethnomathematics: Mathematical Activities in Estimating, Measuring, and Making Patterns. Journal on Mathematics Education, 8(2), 185-198. Doi:10.22342/jme.8.2.4055.185-198

Muhadi, D., Sukirwan, \& Warsito (2019). Ethnomathematics on Sundanese belief symbol. International Journal of Innovation, Creativity and Change. 10(2) 44-55. https://www.ijicc.net/images/vol10iss2/10207_Muhtadi_2019_E_R.pdf

Nangoy, O.M. \& Sofiana Y. (2013). Sejarah Mebel Ukir Jepara. Jurnal Humaniora, 4(1), 257 264. doi:10.21512/humaniora.v4i1.3436

Nasution, A.H. (1980). Landasan Matematika. Jakarta: Bhratara Karya Aksara.

Purnomo, R. \& Kusumandyoko, T.C. (2017). Perancangan Typeface dengan Tema Motif Ukir Jepara. Jurnal Seni Rupa, 5(3), 565-573. Retrieved from https://jurnalmahasiswa.unesa.ac.id/index. php/va/article/view/21618

Rahmawati, A., Triyanto, \& Iswidayati, S. (2017). Seni Relief Desa Senenan: Kajian Estetik, Fungsi, dan Pewarisannya di Sanggar Jepara Carver. Catharsis: Journal of Arts Education, 6(1), 28-37. Doi:10.15294/catharsis.v6i1.17029

Reys, et al. (1984). Dasar - Dasar Matematika. Jakarta: Bumi Aksara.

Rosa, M., \& Orey, D. C. (2007). Cultural Assertions and Challenges Towards Pedagogical Action of an Ethnomathematics Program. For the Learning of Mathematics, 27(1), 10-16. Retrieved from https://flmjournal.org/Articles/7E5EFFA4B24CB97110973C060200F3.pdf

Soepratno, B.A. (2004). Ornamen Ukir Kayu Tradisional Jawa 1: Keterampilan Menggambar dan Mengukir Kayu. Semarang: Effhar dan Dahara Prize. 
Sugiyono. (2019). Metode Penelitian Kuantitatif, Kualitatif dan R \& D (2nd ed). Bandung: Alfabeta.

Sukasno. (2012). Problematika Pembelajaran Matematika di SD. Jurnal Perspektif Pendidikan, 5(1), 107-114. Retrieved from https://www.ojs.stkippgrilubuklinggau.ac.id/index.php/JPP/article/view/354

Sunarto, A. (2009). Ornamen Nusantara: Kajian Khusus Tentang Ornamen Indonesia. Semarang: Dahara Prize.

Utami, R.N.F., Muhtadi, D., Ratnaningsih, N., Sukirwan, \& Hamid, H. (2020). Etnomatematika: Eksplorasi Candi Borobudur. Jurnal Penelitian Pendidikan dan Pengajaran Matematika, 6(1), 13 - 26. Doi:10.37058/jp3m.v6i1.1438 